\title{
Otakar Zich on Dramatic Acting
}

\author{
Martina Musilová
}

\begin{abstract}
This study deals with Otakar Zich's conception of dramatic acting as defined in his 1931 The Aesthetics of Dramatic Art and the historical context in which the concept was formed, e.g. within the first generation of Czech Modernism in the 1890s of which Zich was a member. Zich's aesthetics were influenced by (1) experimental psychology, particularly the associationism Zich adopted from his professor František Krejčí; (2) a theory of the work of art developed by first-generation Modernists under the influence of Richard Wagner; and (3) Nietzschean individualism. Coming from this background, Zich could not fully anticipate the tumultuous developments in theatre during the interwar period, especially the latest practical and theoretical innovations in the field of anti-illusionistic avant-garde acting.
\end{abstract}

\section{Key words}

Zich, acting, modernism, embodiment

The paper is an outcome of a research project Divadlo jako syntéza uměni: Otakar Zich v kontextu moderní vědy a dnešní potenciál jeho konceptů / Theatre as Synthesis of Arts: Otakar Zich in Context of Modern Science and Actual Potential of His Concepts (GAČR 2016-2018, GA16-20335S). 
In Otakar Zich's estate, critical commentaries were found likely written by Zich on Alexander Tairov's Notes of a Director, a work published in Czech in 1927. Zich disagreed with the Russian avant-garde director and his concept of acting. In my study I look at Zich's concept of the dramatic acting as it is presented in The Aesthetics of Dramatic Art (1931). Most importantly, the present analysis considers the historical context centring on the first generation of Czech Modernism of the 1890's, a movement in which Zich was prominent. The cultural context that shaped Zich's relationship to dramatic theatre did not allow him to accede to Craig's concept of the unity of actor work - material, to which Tairov had responded by seeking stylized forms of acting.

At the outset of my study I would like to point out three precepts that should be specified in advance. First, Otakar Zich was a practitioner of experimental aesthetics, a field of psychology which uses analysis of individual experience as a central method. In this field Zich followed his professor František Krejčí, a subscriber to the concept of associationism (KREJČÍ 1897). We can find Krejčís influence in Zich's essay 'The Aesthetic Preparation of the Mind' (ZICH 1921) and in his definition of dramatic character (dramatická osoba). Associationists reduce the process of associations and the interpretation of impulses to the sphere of consciousness, thus denying Freudian or Jungian concepts of the unconscious. In associationism, the sphere of psyche and consciousness is identical, with mental processes conceived as series of successive psychological elements; emotional and volitional operations are thus accentuated. From my point of view, Zich's concept of psyche based on associationism determines his understanding of an individual, and consequently of a dramatic character and stage figure. ${ }^{1}$

The second influence I would like to mention is that of certain strains of modernism. A member of the first generation of Czech Modernism, Zich was critical of Richard Wagner's reforms both during the Wagnerian cult and after it had subsided (ZICH 1959: 245). The predominant concept of kunstwerk (work of art) of that period enabled Zich to conceive of the dramatic art or the art of the actor as a specific entity. Besides Wagner, Friedrich Nietzsche had the strongest impact on Czech modernists of the first generation in the 1890's, with the concept of individualism most typical for the Czech modernist variation of Nietzscheism. ${ }^{2}$ Most innovations in the field of art of that period were formed and determined by individualism, with the main representative in theatre often claimed to be the actor Eduard Vojan. It was within this cultural milieu that Zich began studies at Charles University in Prague, and we can presuppose that his first spectator experiences of the theatre were framed by the concepts of individualism and work of art.

The fact that the crux of Zich's artistic education lies in music and opera is the third precept to emphasise. We have no evidence that Zich was in close contact with any theatre practitioner that would correspond to the contacts German theatrologist Artur Kutscher had to Frank Wedekind, or Max Herrmann had to Max Reinhardt. It can be

1 See (OSOLSOBĚ and PROCHÁZKA 1986). Notes and comments (ZICH 1986: 365, note 217).

2 Czech Nietzscheism was often intermingled with certain ideas of Schopenhauer or Darwin, as we can see in the studies of František Krejčí. 
said that Zich's focus on opera limited his ability to understand various problems of acting in their complexity.

\section{Continuity and unity of the stage figure and dramatic character}

Zich's statements regarding the continuity and unity of dramatic character (ZICH 1986: 105) are the strongest and most provoking impulses for critical analysis of his concept of character - both dramatic as well as human. The period of 1913-1931 during which Zich was working on his book The Aesthetics of Dramatic Art is parallel to the period of a huge development in Czech theatre that took place through specific stages. After the first generation of modernism of the 1890's, a new phase affiliated with the magazine Scéna was entering the theatre just before the Great War. I call this phase of Czech modernism the second generation to distinguish it as the generation of avant-gardists who arrived in the theatre later in the mid 1920's. The reception of Nietzsche's ideas of artists and theorists of the second modernist generation is much deeper and it is combined with vitalism and impulses from avant-garde art such as Picasso's cubism and Marinetti's futurism. The personal experiences of this generation of World War One accelerated changes in the artistic approaches that had been established before the war. The critic Miroslav Rutte commented on this transformation in 1929: 'The old realism was blasted out of existence by shrapnel [...]' (RUTTE 1929: 21). ${ }^{3}$

The changes in Czech theatre after the war become evident if we trace an overview of the theatre repertoire before and after the Great War. In the pre-war period, we can see the dominance of Ibsen, Strindberg, neo-romanticism and psychological realism. In the post-1918 period, the new relativistic drama represented by G. B. Shaw, Luigi Pirandello, František Langer, the Čapek Brothers, Jan Bartoš and other writers and artists had arrived to great public acclaim. A contemporary critical reflection on new trends in this period of drama written in 1929 by František Götz can help us understand changes in the views on human character that had occurred by this time as well as how psychology had changed as a result of a new conception of time. According to Götz, the human observes itself in the stream of time: 'psyche ceases to constant, becoming a stream of inner synthesis, changing every moment' (GÖTZ 1929: 10-11). Götz argues that drama was altered by this 'temporalization' and a consequence of this change is the weakening of dramatic conflict. Götz continues his observations by focusing on the question of character and individuality: 'In the new epoch individuality disintegrated into a stream of heterogeneous states and complexes. [...] individuality was once a stable entity of character [...] today it is disconnected and disjointed' (GÖTZ 1929: 11).

As described by Götz, emotions found their expression in the stage works of Karel Hugo Hilar, a Czech director acquainted with German theatre theory. One year after the publication of The Aesthetics of Dramatic Art, Hilar wrote an essay in which he analyses Artur Kutscher's Die Elemente des Theaters (1932): 'Kutscher has his own psychological 
term for characterization in the modern actor that was inspired by Jewish dualism [...] a term describing a split, contradictory, disrupt, bidirectional, bipolar character comes closest to the demands that modern time puts on the actor's art' (HILAR 1932: 13). We can interpret Hilar's words as a reflection of the leading tendencies of Czech theatre acting of the preceding decade of the 1920's. In his essay, Hilar emphasises a dynamic conception of character of the human psyche and dramatic personas.

If we go back to the time of Zich's youth and university studies, we find a completely different view represented by the founder of Czech modern acting art Eduard Vojan (1853-1920), whose basic attitude and the 'general theme' of his stage creations were extraordinary individualism and aristocratism (HYVNAR 2008: 28) as an opposition to the banality and narrow-mindedness of the petit-bourgeois (VODÁK in CÍSA $\check{R}$ 2006: 189). Vojan constructed his character-figures as would an architect (KODÍČEK 1926: 47), with each detail the exact indication of a specific moment in the action or of an inner state, a process in which each detail, each movement, each position in the physical structure of the construed figure communicates meaning. Vojan's technique entailed the exploration and, finally, the domination of body movement and expression: gestures, facial expressions, posture, along with the use of characteristic walks and other movements. Vojan's most famous characters emerged from the works of Chekhov, Gorky, Ibsen, Hauptmann and especially Shakespeare. ${ }^{4}$

\section{Reception of an actor or of an acting actor}

Zich devised the term semantic image (or simply - the image; významová predstava) to explain the spectator perception enriched by her/his own associations. Zich further divides semantic image into two interconnected types in the context of performance: the technical image (významová predstava technická), such as that of an actor or a physiological attribute of perception, and symbolic image (významová prèdstava obrazová), for example, Hamlet or a psychological attribute of perception. According to Zich, the image is based on our knowledge of the theatre and its practise (ZICH 1986: 43).

In proposing these terms, Zich is attempting to resolve a basic problem discussed in all (or nearly all) modernist theories of acting - the unity of actor-creator, actor-material and actor-work of art. As Zich continues to focus his concepts through a prism of perceptual and empirical aesthetics based on experimental psychology, he cannot include the phenomenon of the 'double existence of actor in a play' (FINK 1968: 23). Unlike Coquelin, Craig, Meyerhold and especially Tairov, Zich refuses to link together the actor and his work of art. The awareness of the double existence of an actor in a play is a cultural fact, framing our perception of the theatre illusion, but it is not the immediate perception that Zich is looking for. Distinguishing the spectator perception into the terms technical image and symbolic image, Zich tries to explain the phenomena that

4 In Zich's estate we can find Jan J. Bor's monograph Eduard Vojan (1907) - see (OSOLSOBĚ and PROCHÁZKA 1986). Notes and comments (ZICH 1986: 333, note 8). 
Valery Bryusov and the avant-gardists understood as a conventional character within theatre art. While the avant-gardists turned the phenomenon of theatre convention into a key component to react against in their anti-illusionist aesthetics, Zich stays somewhere in between illusionism and anti-illusionism. Ivo Osolsobě comments on Zich's term technical image, purporting that the spectator's perception is not the physiological actor but the acting actor (or performing actor) (OSOLSOBĚ and PROCHÁZKA 1986: 340, note 43). I would add that the perception of the acting actor in the sense of technical image can awake the spectator's associative process explored in avant-gardist anti-illusionistic theatre.

\section{Transfiguration of an opera singer or embodiment of an actor}

As Zich analyses the process of creating and performing the stage figure in his fifth chapter entitled 'Dramatic Character', he wants to explain the process of the transfiguration of an actor. He uses the Czech term přetělesněni, which is close to Russian воплоще́ние (Stanislavski), and English embodiment (CARNICKE 2009: 217) or physical transfiguration. The question if we should use transfiguration or embodiment in translating the Czech term pretělesněni to English lies in Zich's concept of stage figure as an actor's work of art, which Zich distinguishes from the notion of the actor as material and creator.

The actor has an awareness of his double existence, however greatly reduced this awareness may be (FINK 1968: 23). Stanislavski uses the term the sense of self to describe the double existence of an actor: "the "Sense of self" combines two conscious perspectives: being on stage and being within the role. In other words, the "Sense of self" is Stanislavsky's term for the actor's dual consciousness made familiar by the French philosopher Denis Diderot' (CARNICKE 2009: 224). ${ }^{5}$ Influenced by interwar German theatrology, Miroslav Rutte explains in 1946 how in his view the actor is constantly forced to split his consciousness into a creative side and a reflective side (RUTTE 1946: 23).

Zich's description of the reflexive process in acting during the phase of automation (the last phase of creating the stage figure) emphasises the reflective side of the journey: 'the observing $I$ is his own [that of the actor], while the observed $I$ is transfigured mentally, so it has been already relatively estranged' (ZICH 1986: 128). If this were so, then Craig would be right when he says that the actor is unable to control his/her art of work. In such a case the actor would not fuse with the figure but, conversely, always maintain an objective distance from it. ${ }^{6}$

From my point of view, Zich underestimates the importance of several issues: (a) the unity of the actor and the actor's material; (b) the capriciousness of this material (the human body); and (c) the actor's inability to fix the stage figure in a definite form. The actor's embodiment is a process controlled and validated by the actor's reflective

5 See more in (STANISLAVSKI 2010: 456-462, Chapter 'Perspective of the actor and the role').

$6 \quad$ Zich corrected Craig's position in the commentary (ZICH 1986: 130). 
activity during all phases of creation: (a) searching for the form of a figure; (b) rehearsing and refining it; and (c) performing it in a perceptive interference with the audience. In contrast with the opera singer, the drama actor has no support in communicating the stage figure's emotions. The opera singer can lean on the libretto ( $d r a-$ matic text) but also on the musical notation that reprises, coincides with, or anticipates, the emotions he/she has experienced, is experiencing or will experience at any given time. Zich's practical artistic experience was gained in the sphere of opera. While Zich simplifies the process of pretělesněni - as I have suggested - this presents a problem: in opera, one might use the English word transfiguration. Yet in spoken drama this term is insufficient, as the word embodiment is more precise and appropriate. With most of his practical experience coming from opera, Zich fails in distinguishing this nuance.

\section{In conclusion}

Rooted in empirical methods, Zich's aesthetics has its limits, as it does not reflect contemporary changes in modern psychology nor the new concepts regarding the human psyche (Freud, Jung, behaviourism, Gestaltpsychologie). From this point of view, Zich could not accept Tairov's plastic and phonetic forms concepts of acting that are analogical to the abstractionism in visual arts of 1920's and 1930's. Neither could Zich appreciate the concept of the human character represented by the new relativistic drama, which was less revolutionary than that of Tairov. Zich's aesthetics thus prevents us from understanding certain forms of post-1918 theatre and therefore some of Zich's statements on acting should not be adapted too literally.

\section{Acknowledgements}

I would like to express my gratitude to Professor Pavel Drábek and Tomáš Kačer, PhD, for advice on translations and language expertise.

\section{Bibliography}

BOR, Jan Jaroslav. 1907. Eduard Vojan. Praha: Hejda a Tuček, 1907.

CARNICKE, Sharon Marie. 2009. Stanislavsky in Focus: An Acting Master for the Twenty-first Century. London: Routledge, 2009.

CÍSǍ̌, Jan. 2006. Přehled dějin českého divadla [An Overview of Czech Theatre History]. Prague: AMU, 2006.

FINK, Eugen. 1968. The Oasis of Happiness: Toward an Ontology of Play. Yale French Studies 41 (1968): 19-30.

GÖTZ, František. 1929. Několik otázek aktuální dramaturgie [Several Problems in Contemporary Dramaturgy]. In Miroslav Rutte and Josef Kodíček (eds.). Nové české divadlo 1928-1929: 
Sbornik dramatického svazu [New Czech Theatre 1928-1929: Proceedings of the Drama Union]. Prague: Aventinum, 1929: 9-14.

HILAR, Karel Hugo. (1932). O pramenech hereckého tvoření [On the Sources of Actors' Creative Work]. In Miroslav Rutte and František Götz (eds.). Nové české divadlo 1930-1932 [New Czech Theatre 1930-1932]. Prague: Aventinum, 1932: 5-16.

HYVNAR, Jan. 2008. O českém dramatickém herectvi 20. stoleti [On Czech Dramatic Acting in the $20^{\text {th }}$ Century]. Prague: KANT, 2008.

KODÍČEK, Josef. 1926. Cesty nového divadla [Directions of the New Theatre]. In Josef Kodíček and Miroslav Rutte (eds.). Nové české divadlo 1918-1926 [New Czech Theatre 1918-1926]. Prague: Aventinum, 1926: 5-9.

KREJČÍ, František. 1897. Zákon associačni (pokus psychologický) [Laws of Association (A Psychological Experiment)]. Prague: Česká akademie císaře Františka Josefa pro vědy, slovesnost a umění, 1897.

OSOLSOBĚ, Ivo and Miroslav PROCHÁZKA. 1986. Poznámky a komentáře [Notes and Commentaries]. In Otakar Zich. Estetika dramatického uměni [The Aesthetics of Dramatic Art]. Prague: Panorama, 1986: 329-372.

RUTTE, Miroslav. 1929. České drama a vývoj [Czech Drama and Its Development]. In Miroslav Rutte and Josef Kodíček (eds.). Nové české divadlo 1928-1929: Sbornik dramatického svazu [New Czech Theatre 1928-1929: Proceedings of the Drama Union]. Prague: Aventinum, 1929: 21-28. RUTTE, Miroslav. 1946. O uměni hereckém [On Acting]. Prague: Jos. R. Vilímek, 1946.

STANISLAVSKI, Konstantin. 2010. An Actor's Work. Transl. and ed. by Jean Benedetti. London: Routledge, 2010.

TAIROV, Alexander. 1927. Odpoutané divadlo. Zápisky režiséra [Liberated Theatre. Notes from a Director]. Prague: Orbis, 1927.

ZICH, Jaroslav. 1959. Hudební svět Otakara Zicha [The Musical World of Otakar Zich]. Živá hudba [Live Music] 1 (1959): 227-246.

ZICH, Otakar. 1921. Estetická př́íprava mysli [The Aesthetic Preparation of the Mind]. Česká mysl [Czech Ideas] 17 (1921): 150-162, 193-204.

ZICH, Otakar. 1927. Jak se komponuje opera [How to Compose an Opera]. In Josef Kodíček a Miroslav Rutte (eds.). Nové české divadlo 1927 [New Czech Theatre 1927]. Prague: Aventinum, 1927: 86-89.

ZICH, Otakar. 1986. Estetika dramatického uměni: teoretická dramaturgie [The Aesthetics of Dramatic Art: A Theoretical Dramaturgy]. $2^{\text {nd }}$ ed. Prague: Panorama, 1986. 


\section{Doc. Mgr. Martina Musilová, Ph.D.}

Department of Theatre Studies, Faculty of Arts, Masaryk University, Gorkého 57/7, 602 00, Brno, Czech Republic

martina-musilova@seznam.cz

Martina Musilová graduated in theatre studies from the Faculty of Arts at Charles University in Prague, where in 2007 she successfully defended her thesis, which was published in 2011 under the title Fauefekt. Vlivy Brechtova epického divadla a zcizujícího efektu $\checkmark$ českém moderním herectví [The Influences of Brecht's epic Theatre and the Alienation Effect on Modern Czech Acting]. During her university studies she attended Professor Ivan Vyskočil's lectures Dialogical Acting with an Inner Partner at the AMU Theatre Faculty in Prague. Since 1999 she has been assisting in teaching this discipline. Since 2009, she has been employed at the Department of Theatre Studies at the Faculty of Arts at Masaryk University in Brno. She also cooperated with the Department of Theory and Criticism in 2013-2019 and has been working at the Department of Authorial Creativity and Pedagogy at the AMU Theatre Faculty in Prague since 2019. She specialises in the history and theory of acting and the theatricality of public events. 